\title{
Universiteit
}

Leiden

The Netherlands

\section{Violence and history: a response to Thandika Mkandawire \\ Ellis, S.}

\section{Citation}

Ellis, S. (2003). Violence and history: a response to Thandika Mkandawire. Journal Of Modern African Studies, 41(3), 457-475. doi:10.1017/S0022278X03004324

Version: $\quad$ Not Applicable (or Unknown)

License: $\quad$ Leiden University Non-exclusive license

Downloaded from: https://hdl.handle.net/1887/9512

Note: To cite this publication please use the final published version (if applicable). 


\title{
Violence and history: a response to Thandika Mkandawire
}

\author{
Stephen Ellis*
}

I N T R O D U C T I O N

Last year, Thandika Mkandawire (2002) published an article in the fournal of Modern African Studies proposing 'an explanation of the violence against the peasantry' in Africa, referring to people in rural areas who have suffered so much in recent wars across the continent. The article starts by categorising suggestions made by some other authors as to why combatants have used 'extremely brutal and spiteful forms of violence' in such a disturbing number of cases. In the opening section of his paper, Mkandawire takes exception to suggestions I have made concerning the antecedents of the I99os civil war in Liberia, describing my views as 'essentialist' and 'poorly veiled racist', and alleging that I believe 'there is something fundamentally wrong with African culture' (2002: I83).

These tags are inaccurate to designate my own views on the matters he refers to, which I will shortly describe in more detail. Nowhere in the text that he so dislikes do I actually refer to either race or 'African culture'. 'Culture' I take to be the meanings, changing over time, that are generally attributed in a given community to repertoires of action. I do believe that culture in this sense is a concept that can be used for analytical purposes; it should, like other analytical instruments, be handled with precision. In my view, there can never be anything fundamentally 'wrong' with any cultural pattern, although the political use that is made of certain widely held ideas may be deleterious in any part of the world. The idea that distinct, definable, homogeneous cultures exist is inaccurate. Similarly, 'race' is a social construct - not a biological category - that I have never used. As for an 'essentialist' argument, if, as Mkandawire suggests, it is the assertion that a given group of people have 'culturally encoded genes', which cause them to commit 'atrocious acts', then my arguments do not belong in that category either.

* Afrikastudiecentrum, Leiden, The Netherlands. 
It is not necessary to invoke genetics to explain how patterns of behaviour that have occurred in the past may be reflected in any given society or community. All societies transmit such coded historical knowledge. They do it largely through institutions that transcend the life-span of individual generations - states, for example - which impose on people particular forms of action that can gain widespread social currency. These socially recognised forms of action, although evolving over time, inevitably reflect ideas and practices that were current in the past. Historical patterns of behaviour are inculcated in every child through education, whether formal or informal, through rituals and games, and through learned behaviour in the broadest sense. The mode of transmission may be written documents, but also stories told by word of mouth, moral injunctions, and forms of behaviour that people, through social contact, learn are expected of them. Such knowledge, derived from historical precedents, can also be transmitted through objects that are vested with meaning, such as flags, buildings, religious artefacts, and even landscape. Although nowhere in the paper that Mkandawire criticises do I refer to 'Liberian culture' or 'African culture', as he suggests I do, I would indeed say that all historical knowledge is transmitted in culturally coded form.

My views on these matters are contained not only in the paper on the Liberian civil war (Ellis 1998) that Mkandawire has referred to, but also in a full-length book that, curiously, he has not cited (Ellis I999). Briefly, my argument is that the civil war in Liberia, or at least the phase of it that lasted from I989 to I997, was about money, power and revenge, like most wars. Its causes were complex. But the war was not inevitable, in the sense that its most immediate cause was the greed, miscalculation, insouciance or ruthlessness of various key players including (in alphabetical order) James Baker III, George Bush Senior, Samuel Doe, Moammar Gadaffi, Félix Houphouët-Boigny and Charles Taylor. There was an unusual conjuncture of events that a religious believer might attribute to the hand of God, a conspiracy-theorist to some fiendish plot, and many readers of academic books might regard as bad luck or coincidence - most notably the fact that in August I990, at the very climax of an uprising against the Liberian president Samuel Doe, Iraq invaded Kuwait, thus diverting the attention of the US government and some other key players, and changing the whole context of the Liberian struggle.

The prime aim of my book The Mask of Anarchy was not, however, to examine the causes of the Liberian war, but rather to explain why the violence took certain distinctive forms. Consideration of this question I believe provides an insight into the historical experience of Liberians over a long period. One of the most penetrating writers on violence, the 
philosopher Walter Benjamin (I986: 284), considers that a failure to consider the moral and historical aspects of violence deprives any specific act of violence of its meaning, and beyond this it prevents the possibility of detecting 'any meaning in reality itself, which cannot be constituted if "action" is removed from its sphere'.

I suggest that the method I have used to analyse the violence of the Liberian civil war could be usefully applied to any violent situation in any part of the world. This could include not only large-scale armed conflict but also, for example, distinctive patterns of 'private' violence, such as that within families. Accordingly, I will first consider Mkandawire's suggestion as to why particular forms of violence occur in African wars, explaining why it is generally unsatisfactory, after which I will consider an alternative method for examining the question of large-scale violence in Africa, one broadly similar to that used in my study of the Liberian war.

\section{I T Y A N D COUNTR Y}

After introducing his paper, Mkandawire moves on to advance his own suggestion as to why so many armed movements in Africa in recent years have tended towards extreme violence. In brief, he argues that many armed opposition movements in Africa have been organised or supported by people from cities. Usually, their aim is to capture control of the state, whose nerve-centre is located in the capital city. But the balance of military power is such that they are generally unable to wage a successful campaign of urban guerrilla warfare. Armed opposition groups of this sort are therefore forced to retreat to the countryside. There, they may have difficulty attracting peasants to their cause. The reason for this is that peasants in Africa, although massively exploited, generally through the mechanism of markets, are at least in possession of the means of production, namely land and labour. Almost nowhere in Africa are peasants oppressed by a landlord class, as they are in some other parts of the world. Although African peasants often take evasive action of various sorts against the state, this tends to fall short of armed insurrection. Hence, rebels find it difficult to generate enough support among the peasantry to mount a Maoist-style, rural-based, guerrilla campaign. 'Retreating to the countryside', as Mkandawire (2002: I8I) puts it, 'rebels can rarely swim among the peasantry like Mao's fishes in the sea'. Consequently, often being unable to develop a permanent rural base where they can live in a relationship of symbiosis with the peasantry, rebels may be forced constantly on the move, living from predation. According to an observation made by some analysts of warlords in Chinese history, 'stationary' and 
'roving' bandits have very different relations with the peasants whom they move among. 'Stationary bandits are dependent on the prosperity of the communities that they inhabit, and will therefore adopt measures that facilitate such prosperity ... Roving bandits, in contrast, are constantly on the move ... They thus tend to be extremely predatory and destructive' (2002: 199-200). Among the factors that tend to induce rebel movements in Africa to adopt a roving nature are their 'urban origins and agendas'; 'their ideological fuzziness and leadership problems'; the fact that their agendas often do not correspond with those of rural societies; and 'the extreme ethnic fragmentation of the African countryside' (2002: 200). Mkandawire points out that these are broad generalisations, and are therefore not absolutely accurate. Even the most disciplined rebel groups may at times roam the countryside and become predatory, while, by the same token, even essentially roving groups may at times stay in one place and develop some sort of relationship with the peasants they live among.

Mkandawire's explanation for the type of violence used in African wars is unsatisfactory on several counts. Most obviously, the distinction he makes between rural and urban populations, even making allowance for the degree of imprecision inevitable in almost any general statement about a whole continent, does not fit the empirical evidence closely enough to have any explanatory power. For example, some analysts might think that the first of Africa's postcolonial rebel movements to show a consistent pattern of atrocious violence was RENAMO in Mozambique (Vines I99I : I), and yet this was almost entirely a rural movement. It appears that few of its foot-soldiers or even its leaders had lived for long periods in cities before they became caught up in war. Similarly, one of the most vicious rebel or bandit groups in operation today, the Lord's Resistance Army in northern Uganda, is also a rural movement.

Other movements particularly notorious for their brutality, such as the Revolutionary United Front (RUF) in Sierra Leone and the various warlord armies in Liberia during the I99os, were probably more complex from a sociological point of view. It has been established that some of the founders of the RUF had been influenced by quasi-Marxist and panAfricanist ideas current among Freetown-based intellectuals in the rg8os (Abdullah \& Muana 1998: I74-6), although very few members of panAfricanist radical movements actually joined the RUF. During the first stage of its insurrection, the RUF relied heavily on mercenaries or other professional fighters from Liberia and Burkina Faso. No thorough analysis has been made of who precisely the RUF's foot-soldiers and field commanders were, but the available evidence suggests they included both unemployed youths of urban origin, whom some analysts refer to as 
'lumpens' (1998), and large numbers of disenchanted youth from rural areas. Quite a few of these were abducted from small towns and villages rather than being volunteers. Others were recruited while they were working as labourers in the diamond fields. Sierra Leone is rather a small country, offering limited possibilities for an armed group to range over wide areas: some districts were subjected to hit-and-run raids, but others were under more or less continuous RUF control for considerable periods of time; the RUF had a simple but efficient command structure based on territorial units. In short, the RUF cannot be accurately described either as an urban movement forced into the countryside or as a collection of 'roving' bandits. ${ }^{1}$

In regard to the Liberian war, when this began in I989, the invading National Patriotic Front of Liberia (NPFL) was sponsored by a number of professional politicians, who organised its financing and weapons supplies, and supported the fighters in the crucial sectors of diplomacy and propaganda. Its actual field commanders were mostly former professional soldiers like Prince Johnson, Elmer Johnson (no relation) and others trained in Burkina Faso and Libya. Elmer Johnson could accurately be described as an urban intellectual, since he had a degree from Boston University in the USA. Prince Johnson, although coming from a poor rural family, had been raised by an uncle in Monrovia. In any event, the NPFL's core of professional fighters was small. ${ }^{2}$ Most of its combatants were rural youths who rallied to the cause. There is every reason to believe the description of the first phase of the war given by Charles Taylor, who was to emerge as the undisputed leader of the NPFL during the course of I990, when he said that 'As the NPFL came in we didn't even have to act. People came to us and said "Give me a gun. How can I kill the man who killed my mother?" '(Berkeley 1993: 54).

This was the situation of the NPFL during the first year of the Liberian war, which was exactly the period that the international press paid particularly close attention to it, establishing its media reputation as a war of exceptional brutality. Although Western journalists often gave particularly lurid descriptions of the violence they witnessed, and were fascinated by the unusual costumes of many fighters, many West African observers also regarded the war as extraordinarily brutal (e.g. Brehun I99I). Probably IO-I5,O00 people were killed in the first year of Liberia's war, the vast majority of them non-combatants. Many atrocities were committed by people intent on taking revenge on the government of Samuel Doe. Thousands of Krahn and Mandingo people, considered to be Doe supporters en masse, were massacred, even when they were not suspected of having personally worked with the Doe government, on account of their 
ethnic identity alone. The NPFL fighters who committed many of these atrocities were, at that early stage of the war, subject to very little hierarchical organisation and had had little or no training. The great majority of them were not professional fighters but simply ordinary young men and women, mostly from the rural areas of Nimba County, doing what they believed was right. By the same token, Doe's armed forces also launched ethnic massacres. In the latter case, the victims were Gio and Mano people considered guilty by association with the rebels. Doe's forces, however, had a well-deserved reputation as hardened killers. Many of them had received US and Israeli training, and these professionals were joined by 'I990 soldiers', mostly Krahn and Mandingo youths and men who joined up to protect their communities and take revenge for NPFL massacres. After 1990, the original two protagonists, the Doe forces and the NPFL, were to evolve and spawn new militias. The NPFL became much better organised. Although there has been no sophisticated analysis of who exactly composed the numerous warlord armies that emerged in Liberia later in the I990s, it is clear that they cannot be easily categorised as either urban or rural, nor as stationary or roving. All of them aimed to control a core territory and to derive income from it. All of them were intent on economic exploitation, ranging from individual looting to sophisticated deals with specialist operators, such as foreign firms and professional import-export traders. African, American, Asian, European and Middle Eastern companies or individuals all participated in the war economy in this way (Ellis I999: I64-80).

These examples from Mozambique, Uganda, Sierra Leone and Liberia could be supplemented by reference to other armed conflicts. Taking into account the literature on armed groups or guerrilla armies in Africa, ${ }^{3}$ one could perhaps generalise by saying that it is probable that many rebel groups operating in recent years have been composed of people from both city and village or, more likely, of people who have spent much of their lives in between the two and cannot be easily described as either city people or village people. Some movements are led by people who cannot be accurately regarded as having an urban background. In other cases, it may be that the political representatives of a rebel movement tend to have a different background from field commanders. Again referring to cases from across the continent, it is inaccurate to say, as Mkandawire (2002: I93) does, that 'there are no urban guerrilla movements in Africa in the sense of movements whose fighting terrain is urban'. Bangui, Brazzaville, Bujumbura, Freetown, Kigali, Monrovia and Mogadishu are all capital cities that witnessed pitched battles in the I99os, as Ndjamena did a decade earlier. Kinshasa has been the scene of massive looting more than 
once. Provincial cities like Huambo, Hargeisa and Kisingani have also suffered major bombardments. Koidu, the diamond capital of Sierra Leone, was entirely destroyed in the late ig9os. The relationship between cities and their hinterlands in time of war seems to be complex. The leading researcher on successive campaigns in Brazzaville, for example, detects a shift in the pattern of violence between I994, when combatants were overwhelmingly inhabitants of the city itself, and later bouts in 19989, when many were of provincial origin (Bazenguissa-Ganga I999: 52-4). Fighters from Brazzaville itself, he notes, often sent looted goods to their villages of family origin with a view to preparing a place of refuge in case they had to withdraw to the countryside, while provincial youths were readier to inflict wanton damage on the capital city. The twin city of Kinshasa, also the capital of a war-ravaged country, has, on the other hand, been remarkably unscathed since the start of the current war in the Democratic Republic of Congo in 1996.

In Angola, Liberia, Sierra Leone and doubtless some other war-torn countries, one of the most notable long-term effects of war has been to drain population from the rural areas as people move in search of safety. Other than crossing the nearest international border and becoming refugees according to international law, many people head for the capital city and acquire the unenviable status of 'internally displaced people' (IDPs). This has led to Luanda, Monrovia and Freetown, the respective capitals of these three countries, becoming massively overcrowded as people displaced from rural areas struggle to survive in what may easily turn into a permanent new home in a city shanty-town. It also has the effect of damaging agricultural production but tends to suck in food aid given by humanitarian organisations, which thus become players in the struggle (Duffield 200I). It would be useful to consider at more length the political economy of this pattern, although that is an ambition beyond the scope of the present article. In heading for the capital city of a country like Angola, Liberia or Sierra Leone, many displaced country-dwellers are heading for the places that are home to the very elites who have been complicit in draining the provinces of their wealth over a long period of time. In all three countries, these same ruling elites, although by no means solely responsible for the violence in the rural areas, manipulate that violence in such a way as to derive benefit from it. Moreover, this pattern seems quite old, and not surprisingly there is evidence that rural people often have a highly ambiguous attitude towards their capital city, which they regard simultaneously as an attractive place but also as a source of corruption and exploitation on which, in circumstances of war, they may take revenge by destroying buildings and plundering what country people 
feel to be rightfully theirs. This was certainly the case in Monrovia in 1990 and Brazzaville in $1998-9$, and almost certainly also in Freetown in 1999.

In short, the sharp rural-urban division posited by Mkandawire does not conform to the available evidence, either in terms of the composition of rebel movements or in the patterns of violence and exploitation. Probably one of the main reasons for this is the complexity of the relations between people living in cities and rural areas generally. There is a vast literature suggesting that many people in Africa move between town and country throughout their lives, and that even confirmed city-dwellers retain complex economic and moral relations with the villages that they regard as their ultimate place of origin, perhaps retaining a claim to ownership of land there and aspiring to build a house and be buried in their ancestral home (cf. Bayart et al. 200I). In many respects people bring a village style of living to the cities. Investigation of the complexity of these relationships could eventually produce a more satisfactory sociological model of the urban-rural relationship in situations of war. However, even if such a model were to be developed, it may supply only limited evidence as to why the violence used by fighters sometimes seems so extreme or gratuitous. Violence is a subject sufficiently complex, and pervasive, as to defy understanding in any single dimension.

THE CONTEXT OF VIOLENCE

"The phrase "senseless violence" is a peculiarly empty piece of huffing and puffing', according to Noel Malcolm, a historian of the Balkans. 'However repugnant violence may be, the one thing it is not is senseless' (quoted in Blok 2000: 24). According to Anton Blok (2000), reputed for his work on the Sicilian mafia and one of a number of scholars currently attempting to investigate the meanings that people attribute to violence that they themselves perpetrate, of which they are victims, or which they observe, violence may be considered 'as a changing form of interaction and communication, as a historically developed cultural form of meaningful action'. For this reason, he suggests, it is important to study violence in its particular context, 'as a historically developed cultural form or construction' (2000: 26). In brief, he suggests that if we wish to study the meaning of a particular act of violence, we must first consider it in the context in which it occurs, since a given act may have a quite different meaning in one time or place than in another. Part of the process of setting an event in context is to examine its antecedents, to see whether it resembles earlier acts or at least is connected to them in some way. Indeed, it seems quite likely that many major acts of violence are committed in imitation of 
earlier such acts. An obvious example of this concerns modern armies that are in a permanent state of training, generally aiming to perfect techniques of inflicting violence that have been learned from earlier wars, or that have been developed with earlier wars serving as a relevant precedent.

A similar element of imitation may also be present in many acts even of violence that are not organised by a state. As I write, I have on my desk an essay reviewing some recent research on the ghastly subject of lynching in modern American history, which has become the subject of renewed popular attention largely as a result of an exhibition of photographs organised by the New York Historical Society in 200I, currently on display in Atlanta, Georgia (Lewis 2002). Lynching derives its name from one Charles Lynch of Chestnut Hill, Virginia, a justice of the peace during the period of the American revolution who was known for his support of summary executions of supporters of the British monarchy. It may be distinguished from other forms of murder and mob violence by a number of specific characteristics related to the identity of actors and victims and the almost ritual sequence of events. In its early period, lynching was not confined to the southern states of the USA, nor was it directed especially against black people. In fact, we are told, 'protected by masters whose community standing generally could not be challenged, slaves had been virtually immune to the sanctions of avenging mobs in the Old South' (2002: 27). During the first half of the nineteenth century, lynching was often considered to be an American virtue, a form of communal justice meted out to outlaws by rugged frontiersmen. This changed after the civil war of $186 \mathrm{I}-5$ and the abolition of slavery. It was during the restoration of white supremacy in the southern states in a new form after about I880 that lynching gained the character that has since become so notorious, an appallingly cruel form of mob violence directed especially against black men, most particularly those accused of raping white women. An informed estimate is that some 3,400 blacks and I, 300 whites were deprived of life without due process in the US between I880 and I945 (Lewis 2002). While lynching had died out by the ig6os and the era of civil rights, it has left a powerful memory, particularly among African Americans. When Clarence Thomas, a black lawyer proposed by the administration as a candidate for membership of the US Supreme Court in I991, was subject to particularly hostile questioning by the Senate judiciary committee before confirmation in his post, his most memorable riposte was to accuse his tormentors of perpetrating 'a high-tech lynching'. ${ }^{4}$

Situating lynching in its historical context is certainly not the only useful way of analysing this practice, but it is one of the most useful for anyone whose interest is in detecting the 'meaning' of lynching in the sense of 
discovering why people did it and what messages they intended to send, and to whom. In its best-known form, it was clearly used as a way of maintaining a social and political order based on subjugation by reference to skin colour in the southern states after the legal abolition of slavery. In this respect, the element of communication conveyed by such an action is of crucial importance, since a similar series of actions carried out in another time and place might carry a quite different significance. Many societies experience killings carried out without due process, sometimes by mobs; not all such episodes of extreme mob violence, however, convey the same message as lynching. For example, a mob in a South African township killing a suspected government informer in the apartheid period, by the form known as 'necklacing', also conveyed a strong message, but of a radically different sort. As Whitehead (2002: I92) observes:

Violence sometimes appears both appropriate and valuable, and is not necessarily understood as dysfunctional and pathological. Accordingly, even careful analyses of Western forms of violence, such as of the Nazi genocide, are not necessarily relevant to the understanding of postcolonial ethnic violence, such as the genocides in Rwanda and Cambodia, precisely because 'genocide' is there mediated through cultural forms with which Westerners are often unfamiliar.

Moreover, the history of lynching illustrates another important principle, concerning the ways in which knowledge of past events can be transmitted from one generation to another, even in the absence of an official institution ensuring such continuity through policy. Lynching was essentially unofficial, even if people holding state office may have participated or allowed it to occur, and it could be perpetuated by informal means even in such a highly developed state as the USA in the twentieth century. The ring-leaders who organised a particular lynching were people who had seen earlier atrocities of the same type, or who had heard or read about them, and were sufficiently aware of what was involved as to give the practice a degree of consistency over time, in spite of its lack of any legal basis.

My own research on violence in Liberia in the Ig9os follows a broadly similar approach to what I have suggested about the study of lynching. For that reason, my book on the subject is divided into two quite distinct parts. The first of these is a short history of the Liberian civil war considered as having lasted from I989 to I997. The purpose of this section is to situate the mass violence of those years in their political context, which includes, most importantly, its international aspect. Briefly, I describe how deeply Liberia was associated with the USA, having been founded by African American settlers, eventually becoming, in effect although not in law, a US protectorate. It developed a system of government dominated by an 
elite of settler families living in Monrovia and a handful of other coastal cities. Over time, the settlers extended their influence into the hinterland, developing in the process extensive networks of patronage that reached their greatest extent under the presidency of William Tubman (I944-7I), who benefitted from US support and received a substantial income in the form of royalties from foreign mining and agricultural firms. This system began to disintegrate by degrees from the mid-I970s for a variety of reasons, but largely because of changes in the international situation. A military coup in I980 led to the establishment of a military dictatorship under Samuel Doe, who, in the final phase of the Cold War, received massive financial and security assistance from the USA. When Doe was attacked by a small group of opponents armed and supported by foreign powers, however, he was abruptly dropped by his former patron, the USA, which no longer regarded Liberia as a strategic asset after I989. The dramatic shift in the balance of power was a main factor in turning the anti-Doe rising into a full-scale civil war. In retrospect, the Liberian emergency was the start of a period of disturbance throughout West Africa that was to lead to war in Sierra Leone and Guinea, and has had an influence on Côte d'Ivoire. Although my book is not primarily concerned with investigating the causes of the Liberian war, these would certainly include the consequences of using government administration and development as a means of individual accumulation (Ellis 1999: 47, I88); social upheaval following a century of rapid and profound change (297) and modernisation (218); the effects of elite political rivalries throughout the West African region and further afield, even in Libya, Europe and the USA (66f); and the activities of foreign firms prepared to make alliances with various rival factions for purposes of their own (Ellis I999: ch. 4).

The second section of the book examines some of the most striking acts of violence, including those that struck many foreigners as particularly odd or otherwise seeming to defy explanation. These include the practice of male fighters dressing in women's clothing, which was not itself a violent act but was often done by fighters preparing for battle; certain forms of mutilation; and documented episodes of fighters eating human flesh. It was not only Western journalists in search of sensation who noticed the latter. For example, a Nigerian officer serving with the ECOMOG intervention force recalled how 'it was not unheard of to see fighters catch a member of an opposing side, especially key personalities, kill and butcher the chest, extract the heart and later eat it, either in cooked or roasted form' (Nass 2000: 157). The same officer also recorded the use of human body parts for what he called 'a wide variety of funny uses' (2000: 158 ). 
Reference to earlier literature shows that these and other patterns of violence in Liberia that seem most in need of explanation had identifiable antecedents, and ones that seem particularly rich in meaning. For example, transvestite dressing is a feature of the transition to adulthood in the rituals of the most widespread initiation societies in Liberia, essentially indicating the perception that a child entering adulthood goes through a dangerous indeterminate zone between male and female identity before finally being confirmed as an adult (cf. Bledsoe ig84: esp. 462-4). Liberians, even those who have never been initiated into one of the traditional societies, are familiar with the symbolism employed by these sodalities, which is shared in many masquerades and popular entertainments. For a young man to dress as a woman at moments when violence is in the air is tantamount to carrying a sign saying 'Look out, I am dangerous' (cf. Moran 1995). One could compare this with the behaviour of English football hooligans in the Ig8os; these did not dress in women's clothing, but, on the contrary, used to sport military-style cropped haircuts and boots, often calling themselves an 'army' or a 'squad', thus displaying symbols of martial status and aggressiveness that everyone in their society would recognise. This is comparable with the fighters of the Liberian war in that both were using a widely understood symbolic language to make a point about what they were doing: looking dangerous. Other aspects of the Liberian violence also had clear antecedents in the rituals of the initiation societies that were the mainstays of public order in much of Liberia in pre-republican times and that survived, often in radically altered form, throughout the twentieth century.

The point of tracing these antecedents is to attempt to identify the meaning that Liberians attribute to such acts. In short, I find that some of the most extreme violence of the Liberian war refers to a range of symbols concerning power that are widely understood and historically rooted. The argument is not that Liberia is going backwards in time - which is impossible - nor that Liberians are inherently worse than other people, nor that the violence was some form of religious ritual. It is not an argument that Liberia's culture or cultures are dysfunctional. Nor is it an argument that all the violence in Liberia was traditional, since some of the dramaturgy was clearly copied from Hollywood videos. The main conclusion to be drawn from the finding that some of the violent actions committed in the war bore a distinct similarity to violence committed, or at least suggested, in religious contexts is that there has existed over a considerable period of time a repertoire of action associated with the idea of acquiring power that is widely understood, and that fighters used this repertoire. The fact that many of these actions were terrifying to others 
served the fighters' purpose. Armies always act in a way that they hope will intimidate others.

One can draw further conclusions from this finding, for it indicates how patterns of religious and political authority have changed in Liberia during the twentieth century. One of the interests of any civil war, from an analytical point of view, is that it offers an exceptional position from which to observe society. A civil war occurs when a society is torn in pieces. It always shows in vivid relief social and political cleavages that may have existed for decades previously but that had not always been easy to perceive. As in many civil wars, in Liberia, once hostilities had begun, individuals also used the circumstances to settle personal scores on a large scale (Ellis 1999: 129). At various stages of the war this inspired ethnic pogroms against specific groups (1999: 74, 86, 92-3, 216). This itself does not tell us much about why the war happened, but it does tell us a great deal about the history of Liberia since the nineteenth century, the nature of the accommodation between Americo-Liberian elites and hinterland peoples, changes in the distribution of power and so on. In so doing, it provides an archaeology of Liberia.

WHO ARE AFRICA'S REBELS?

Trying to discover what people think they are doing when they perform acts of violence is by no means incompatible with using the disciplines of social science to anyalse the broader forces affecting their lives. However, the insights of social science are less compelling than they once seemed, for a variety of reasons. Over the last three or four decades, a number of factors have combined to cause a loss of confidence in the ability of social science to offer explanations in terms that are universally valid. Such factors include the failure of social science, in the form of modernisation theory, to offer a reliable guide for policy-makers intent on developing countries they regarded as 'backward', 'underdeveloped' or 'traditional' (to use the vocabulary of the mid-twentieth century). The failure of modernisation theory has been more marked in Africa, on the whole, than in any other continent. Some thinkers have reacted to this and other shortcomings of a broad range of theories offered by social science during the last century by embracing postmodernist approaches that are suspicious of any attempt to articulate universally valid propositions. Others continue to use older methodologies despite the weaknesses that, in the opinion of the Cameroonian intellectual Achille Mbembe (2001: 7), for example, 'have undermined the very possibility of understanding African economic and political facts'. 
A creeping lack of confidence among social scientists as to whether they can really provide universally applicable explanations makes it all the more important not to ignore people's own understanding of why they act. In my view, this is best done not from a sense of despair - which may be caused by a perception that understanding general causes is impossible but in a more positive frame of mind, open to new insights, with a view to adapting older models of social science to accommodate data obtained from a broader study of human histories than was customary in the earlier twentieth century. For this reason it seems rather foolish to call local ideas 'false consciousness' or 'ideological fuzziness' (Mkandawire 2002: I90) without further investigation. What appears most desirable is a two-step approach that consists, first, in understanding local ideas in their own context, and only then considering the light such ideas may throw on established models of behaviour known to the social sciences. Hence, it is persuasive to argue, as Neil Whitehead (2002: 192) does, that 'Thinking of violence as a cultural form reveals that violence is often engendered not simply by adherence to globalized ideologies such as Christianity, Liberal Democracy, Communism or Islam, but through the regional and subregional disputes whose origins are in the complexities of local political history and cultural practices.'

Thus, the ultimate purpose of paying attention to historical patterns of violence in each case, rather than immediately attempting to fit it into models developed from a social science based on Western precepts, is to understand variations better than we are equipped to do at present. Far from implying that cultures are homogeneous and unchanging ensembles, condemned to misunderstand each other for ever, this approach implies a renewal of the tradition of social science as an attempt to reach a general understanding of humans and their actions.

It may be that, as the colonial period fades into history, a growing number of countries once colonised by Europe, or obliged to adopt institutions of governance in imitation of European models, will adopt institutions and codes of behaviour that have roots in their own precolonial history. This has already become a vital area of intellectual and political contestation. Thus, there are politicians and influential academics who claim that certain types of belief and behaviour are proper to particular cultures only. Some, of whom Samuel Huntington (I996) is the most notorious, claim, by this token, that the world consists of major cultural blocs that would be well advised to keep their distance from each other. There are governments, as in Malaysia, China and perhaps these days the USA too, that claim exemption from criticism of their human rights policies on the grounds that these are based on distinctive cultural values. Interestingly, 
Africans are in increasing numbers making a statement based on a precisely opposite argument by adopting religions that claim to be based on spiritual knowledge of universal value, in the form of the world religions of Christianity and Islam. In considering this, it is instructive to compare current debates about religion and governance with what happens in the field of natural science. In the biotechnology industries, the search for universally valid theories and models has led to an interest in what is known as 'indigenous knowledge'. This refers to knowledge of the natural world that is possessed by people in the non-Western world, but that is not directly accessible to international scientists, since it is not contained in books or on internet sites, but only in the memories of people living in geographically remote areas. It concerns notably knowledge of plants and herbal medicines, considered as a potential boon to the whole of humanity (cf. Juma I989). If knowledge of a herbal medicine held by people living in a rain forest is found by laboratory technicians in California or Switzerland to be scientifically exact and useful, leading to the eventual manufacture of a patented drug, it ceases to be considered as indigenous knowledge and is reclassified as scientific knowledge. It is then deemed to be of universal value, and becomes universally sellable, thanks to intellectual property regimes. Indigenous knowledge, it could be said, is that which is awaiting discovery by scientific and business elites.

The idea that all human knowledge can be examined by qualified specialists with a view to testing its universal validity is witness to the continuing confidence of natural scientists in their ambition to develop sound models of the natural world. How, it may be asked, does this apply to the knowledge of any particular cultural repertoire, whether it is in North America, Africa, or anywhere else? Social scientists, whose province this is, are less sure than they were even thirty years ago how to consider such knowledge. Anthropologists especially have become far more sensitive then they once were to accusations of arrogance or cultural imperialism, and pay lip-service at least to the right of people to think in whatever ways they want. However, politicians, being more serious about power than academics, tend to be less reticent. Any Western politician who wishes to avoid pressure to become involved in a war that is not regarded as of vital strategic importance for his or her own country is likely to represent it as representing a fixed cultural pattern. When Western politicians refer to conflicts in distant countries as being due to 'age-old hatreds', it is almost invariably shorthand for saying 'I see no reason to intervene'. African politicians also make full use of this cynical device. In Kenya, violence politically manipulated or even organised by the national government under the presidency of Daniel arap Moi was often carried out by thugs 
who dressed in traditional costume, enabling the ultimate beneficiaries to describe it as 'ethnic clashes', implying that it was an unavoidable consequence of poverty and underdevelopment (cf. Kagwanja 2003). Similar examples could be cited from South Africa under apartheid, from Nigeria, or any one of a large number of countries. Failure to consider the cultural style of the violence perpetrated in such cases allows those in power to get away with murder. Literally.

Understanding violence, then, is not just of intellectual interest but of vital political importance. Social scientists need to investigate this contested terrain. Personally, I maintain that they can best do so in the belief that all human beings have fundamental qualities, tendencies and abilities in common, and on the assumption that it is possible to reach a sophisticated and informed understanding of what these qualities are, exactly. This is made difficult because many social scientists have lost the conviction that they possess the keys to such understanding, but those who think this way are only partially correct.

Often, the large-scale, organised violence that has occurred in Africa over the last fifty years has been interpreted through the narrow ideological prism of nationalism. It is undeniable that some well-known armed struggles occurring in that time - in Ethiopia, Zimbabwe, Mozambique, Angola and elsewhere - were waged by people who had sophisticated nationalist ideologies. It can be easily demonstrated that such ideologies had some important historical roots in Europe. Quite often, they were related to the philosophy of Marxism, also a European creation. Until the late I980s, many armed movements aspiring to national liberation received support from one or other Cold War patron who had an influence on their ideological style, on their forms of organisation and on their political and military strategies. Some intellectuals analysed these movements in Marxist terms. During the Cold War, armed movements, particularly if they were ranged against a colonial or settler government, could realistically expect to get super-power support and could realistically aspire to take over government. Indeed, a number did exactly that, from Algeria to South Africa.

Today, analysts are faced with the problem of analysing a generation of conflicts that no longer conform to this type. These new conflicts appear to many observers to have no clear ideological pattern, to use forms of violence that have no obvious military explanation, and to be concerned to a large extent with economic gain. Although Mkandawire (2002) has 
examined some attempts to analyse this new generation of wars, he has omitted to mention some of those that are most convincing (e.g. Reno I998; Kaldor 1999) precisely because they attempt to fit Africa's current generation of wars into a changed global context. The Cold War is over, and the nature of government has changed markedly in Africa - and indeed everywhere else - as a consequence. The change in political order is inseparable from the change in warfare, for the two always belong together. Hence, it is of both political and military significance that Europeans over three or more centuries, later joined by the USA, developed a theory and practice of war in which massive violence can be inflicted by very large bodies of men (and these days, sometimes women too) organised by states. This form of war, fought by the trinity of nation, state and army, reached its peak during the first half of the twentieth century. It was exported all over the world, precisely during the period of Europe's expansion that also introduced colonialism. This form of trinitarian war came to form the basis of international rule-making on war, conceived of as a period of intense violence, properly controlled by states, with a clear beginning (such as a declaration of war or a clear act of aggression) and an end (such as a peace treaty or the surrender or collapse of a protagonist state). Wars became conceived of as exceptional interruptions to a state of normality, called peace. Although Western publics are now being introduced to the idea of wars that are not like this, the classical idea of trinitarian war remains strong and continues to dominate international rule-making in this field (van Creveld i99i).

So, although the ideologues of the most prestigious African liberation movements of the Cold War period could conceive of politics as being properly organised by a state, much as did the governments they battled against, this is no longer the case. Politics in many of the world's most troubled countries are no longer state-centred, or at least tenure of state office is used as a strategic site from which to launch a struggle for power that is both political and military. Violence is often used as an instrument to acquire control of markets or valuable resources, or simply as an instrument of mobilisation, or to destroy the power-base of a potential rival (Reno 1998). Many of the movements making use of the most atrocious violence arise in such circumstances, not only in Africa but also in the Balkans, the Caucasus, central Asia and elsewhere (Kaldor i999).

This observation can usefully serve as the starting-point for future investigations of Africa's current wars, as social and political movements that need to be interpreted in the light of changing conditions in the world and in their local context. This is especially difficult because of "the dominant conception of violence in modern societies in which the means of violence 
have long since been monopolised by the state' (Blok I999: 23). In many cases, in Africa, central Asia and elsewhere, some of the most apparently gratuitous or extreme forms of violence occur in places where states have imploded, but also where the history of state monopolies of violence is short. Countries like Liberia and Somalia (and, for that matter, Afghanistan) and many others have historical experiences of war different from the Western experience of defined periods of massive, state-led violence. In some cases, there are clear indications that even within living memory, committing violence for self-enrichment has been considered morally acceptable under certain circumstances, as indeed it is in many parts of the world. The desire for plunder as a motive for war is not to be underestimated. In the widest sense, the relation of war to trade is common throughout the world, as nearly all wars are about economic gain in some respect. Anyone who doubts this may consider the bellicose policy of the US towards the oil-rich Middle East, for example. This economic aspect, however, takes different forms in countries with different experiences of states or their absence.

Such considerations impel scholars to revisit some earlier struggles, including those that were regarded for decades as the paradigms of liberation struggle in Africa, such as in Algeria and Zimbabwe. Both of these countries were once regarded as paradigms of successful liberation wars, but it is impossible to sustain such a view today. In Algeria, the civil war if that is the right phrase to describe it - that has marked the country since the I99os, marked by the most atrocious and indiscriminate violence, cannot be seriously studied without reference to the period of even largerscale violence preceding independence in 1962 , since some of the roots of the current violence reach back to that period (Martinez 2000). Whether the Algerian war of independence was morally justified is perhaps not the first question to be asked: a more urgent historical question is, rather, to establish what exactly the war was about. Recent historiography, notably by Algerian historians (e.g. Harbi I980), has shown beyond any doubt that the Front de libération nationale (FLN) was engaged in a far more complex struggle than that portrayed by nationalist historians. Its leaders were concerned with gaining power, and therefore were more preoccupied with intimidating rival nationalist movements than with attacking the French army. Zimbabwe has been brought to its present state under the leadership of the same party, and even the same individuals, as those who fought against settler rule in the I97os and turned on rival nationalist movements thereafter.

A search for the historical roots of today's violence will require questioning nationalist historiography. This may not be pleasant, and it may 
involve the deflation of some hallowed myths. But it needs to be done if we are to seek to understand current events, including current violence.

\section{NOTES}

I. In addition to the available literature on the RUF, these last remarks are based on two periods of research, in 1998 and 2002, including interviews with former RUF leaders.

2. 'Libya/Liberian trained Special Forces Commando', document in author's possession.

3. A good overview is the collection by Clapham (I998).

4. This phrase has caught on: it produced more than 2,ooo hits on an internet search engine.

\section{R E F E R E N C E S}

Abdullah, I. \& P. Muana. I998. 'The Revolutionary United Front of Sierra Leone: a revolt of the lumpenproletariat', in Clapham, African Guerrillas, I72-93.

Bayart, J.-F., P. Geschiere \& F. Nyamnjoh. 200I. 'Autochtonie, démocratie et citoyenneté en Afrique', Critique internationale I0, I77-94.

Bazenguissa-Ganga, R. I999. 'The spread of political violence in Congo-Brazzaville', African Affairs 98: 390, 37-54.

Benjamin, W. I986 [i955]. 'Critique of violence', in W. Benjamin, Reflections. New York: Schocken Books, 277-300.

Berkeley, B. I993. 'Liberia: between repression and slaughter', Liberian Studies Foumal I8: I, I27-39 (originally published in the Atlantic Monthly, 270, 6, Dec. I992).

Bledsoe, C. I984. 'The political use of Sande ideology and symbolism', American Ethnologist II, 455-72.

Blok, A. 2000. 'The enigma of senseless violence', in G. Aijmer \& J. Abbink, eds. Meanings of Violence: a cross-cultural perspective. Oxford: Berg, 23-38.

Brehun, L. I99I. Liberia: the war of horror. Accra: Adwinsa Publications.

Clapham, C. ed. I998. African Guerrillas. Oxford: James Currey.

Duffield, M. 200I. Global Governance and the New Wars: the merging of development and security. London: Zed.

Ellis, S. 1998. 'Liberia's warlord insurgency', in Clapham, African Guerrillas, I55-71.

Ellis, S. I999. The Mask of Anarchy: the destruction of Liberia and the religious dimension of an African civil war. London: Hurst.

Harbi, M. i980. Le F.L.N. : mirage et réalité. Paris: Editions J.A.

Huntington, S. 1996. The Clash of Civilizations and the Remaking of World Order. New York: Simon \& Schuster.

Juma, C. J. I989. The Gene Hunters: biotechnology and the scramble for seeds. London: Zed.

Kagwanja, P. 2003. 'Facing Mount Kenya or facing Mecca? The Mungiki, ethnic violence and the politics of the Moi succession in Kenya, I987-2002', African Affairs I02 : 406, 25-49.

Kaldor, M. I999. New and Old Wars: organised violence in a global era. Cambridge: Polity Press.

Lewis, D. L. 2002. 'An American pastime', New York Review of Books, 21 November, 27-30.

Martinez, L. 2000. The Algerian Civil War, I990-1998. London: Hurst.

Mbembe, A. 200i. On the Postcolony. Berkeley \& Los Angeles, CA: University of California Press.

Mkandawire, T. 2002. "The terrible toll of post-colonial "rebel movements" in Africa: towards an explanation of the violence against the peasantry', Journal of Modern African Studies 40: 2, I8I-2I5.

Moran, M. I995. 'Warriors or soldiers? Masculinity and ritual transvestism in the Liberian civil war', in C. R. Sutton, ed., Feminism, Nationalism and Militarism. Arlington, VA: Association for Feminist Anthropology/American Anthropological Association, 73-88.

Nass, I. A. 200o. A Study in Internal Conflicts: the Liberian crisis and the West African peace initiative. Enugu: Fourth Dimension.

Reno, W. I998. Warlord Politics and African States. Boulder, CO: Lynne Rienner.

van Creveld, M. I99I. The Transformation of War. New York: Free Press.

Vines, A. I991. Renamo: terrorism in Mozambique. Oxford: James Currey.

Whitehead, N. L. 2002. Dark Shamans: Kanaima and the poetics of violent death. Durham, NG: Duke University Press. 